\title{
Correction to: Depletion
} of acetate-producing bacteria from the gut microbiota facilitates cognitive impairment through the gut-brain neural mechanism in diabetic mice

Hong Zheng ${ }^{1,2,3}$, Pengtao Xu' ${ }^{1}$, Qiaoying Jiang ${ }^{1}$, Qingqing Xu ${ }^{1}$, Yafei Zheng ${ }^{1}$, Junjie Yan ${ }^{1}$, Hui Ji ${ }^{1}$, Jie Ning ${ }^{1}$, Xi Zhang ${ }^{1}$, Chen $\mathrm{Li}^{1}$, Limin Zhang ${ }^{4}$, Yuping $\mathrm{Li}^{2}$, Xiaokun $\mathrm{Li}^{1}$, Weihong Song ${ }^{3^{*}}$ and Hongchang Gao $\mathrm{O}^{1,2,3^{*}}$

Correction to: Microbiome 9, 145 (2021)

https://doi.org/10.1186/s40168-021-01088-9

Following the publication of the original article [1], the author realized that they made a translation mistake between Chinese character and English name for one of the authors' name. Xiaokui Li should be revised to Xiaokun Li.

The original article has been updated.
Published online: 28 July 2021

\section{Reference}

1. Zheng $\mathrm{H}$, Xu P, Jiang $\mathrm{Q}$, et al. Depletion of acetate-producing bacteria from the gut microbiota facilitates cognitive impairment through the gut-brain neural mechanism in diabetic mice. Microbiome. 2021;9:145. https://doi.org/10.1186/s40168-021-01088-9.

\begin{abstract}
Author details
${ }^{1}$ Institute of Metabonomics \& Medical NMR, School of Pharmaceutical Sciences, Wenzhou Medical University, Wenzhou 325035, China. ${ }^{2}$ Department of Pulmonary and Critical Care Medicine, The First Affiliated Hospital of Wenzhou Medical University, Wenzhou 325015, China. Institute of Aging, School of Mental Health, Wenzhou Medical University, Wenzhou 325035, China. ${ }^{4}$ State Key Laboratory of Magnetic Resonance and Atomic and Molecular Physics, Wuhan Institute of Physics and Mathematics, Chinese Academy of Sciences, Wuhan 430070, China.
\end{abstract}

The original article can be found online at https://doi.org/10.1186/s40168021-01088-9.

*Correspondence: weihong@wmu.edu.cn; gaohc27@wmu.edu.cn

${ }^{3}$ Institute of Aging, School of Mental Health, Wenzhou Medical University, Wenzhou 325035, China

Full list of author information is available at the end of the article

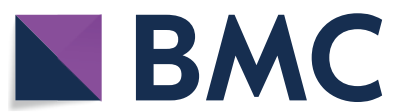

(c) The Author(s) 2021. This article is licensed under a Creative Commons Attribution 4.0 International License, which permits use, sharing, adaptation, distribution and reproduction in any medium or format, as long as you give appropriate credit to the original author(s) and the source, provide a link to the Creative Commons licence, and indicate if changes were made. The images or other third party material in this article are included in the article's Creative Commons licence, unless indicated otherwise in a credit line to the material. If material is not included in the article's Creative Commons licence and your intended use is not permitted by statutory regulation or exceeds the permitted use, you will need to obtain permission directly from the copyright holder. To view a copy of this licence, visit http://creativecommons.org/licenses/by/4.0/. The Creative Commons Public Domain Dedication waiver (http://creativecommons.org/publicdomain/zero/1.0/) applies to the data made available in this article, unless otherwise stated in a credit line to the data. 